\title{
A Primer on the Accounting and Reporting Requirements for Not-for-Profit Organizations
}

\author{
Cole J. Engel, MBA, CPA \\ Department of Economics, Finance, and Accounting, Fort Hays State University \\ 600 Park Street, Hays, Kansas 67601, United States \\ Tel: 1-785-628-5325Ｅ-mail: cjengel2@fhsu.edu
}

Received: January 10, 2016 Accepted: February 1, 2016 Published: April 15, 2016

doi:10.5296/jpmr.v2i1.8843ＵRL: http://dx.doi.org/10.5296/jpmr.v2i1.8843

\begin{abstract}
Over the past 20 years, not-for-profit organizations (NPOs) in the United States and across the globe have become increasingly entrenched in the market economy. NPOs conduct business, employ individuals, and compete in the global marketplace. The federal government, institutions of higher education, and health care organizations are three primary examples of NPOs. Each has much in common with business entities. However, the differences between them have profound implications for financial reporting. This is primarily because they are all required to follow complex accounting and reporting requirements that fall under the jurisdictions of various governing bodies. First, this article explores the establishment of an NPO, discusses the generally accepted accounting principles (GAAP) followed in preparing financial statements, and summarizes the differences between the not-for-profit and for-profit environments. Second, this article explores the accounting and reporting requirements of the federal government, colleges and universities, and health care organizations.
\end{abstract}

Keywords: Establishing Not-for-Profit Organizations, Accounting and Reporting Requirements, Federal Government, Colleges and Universities, Health Care Organizations

\section{Introduction}

Over the past 20 years, not-for-profit organizations (NPOs) in the United States and across the globe have become increasingly entrenched in the market economy. NPOs conduct business, employ individuals, and compete in the global marketplace. In 2008, the number of Internal Revenue Service (IRS) approved tax-exempt entities was greater than 1.9 million, with reported assets of public charities greater than $\$ 2.2$ trillion. From an employment standpoint, NPOs account for over $8 \%$ of total employment, with for-profit entities 
accounting for 75\%, and the remaining 16\% in the public sector. From 2002 to 2004, employment for NPOs grew by $5 \%$, while total private employment grew less than $1 \%$ (Tolbert, Moore, \& Wood, 2010).

NPOs have much in common with for-profit businesses. However, the differences between the two environments have profound implications for financial reporting. NPOs serve entirely different purposes than for-profit businesses and they are accountable to different groups of people. In particular, NPOs are accountable primarily to donors and grantors, while for-profit entities are accountable to owners and shareholders. More specifically, a public charity is incorporated with the purpose of serving the public, and is therefore accountable to the public at large (Granof, 2005).

Every accounting issue that has an impact on NPOs has its equivalent in the for-profit environment, but the differences between the two are so distinct that separate accounting principles and practices are warranted (Granof, 2005). As a result, in 1979 the Financial Accounting Standards Board (FASB) assumed primary responsibility for setting standards for both for-profit businesses and NPOs (Wilson, Kattelus, \& Reck, 2007). This section explores the establishment of an NPO, discusses the generally accepted accounting principles (GAAP) followed in preparing financial statements, and summarizes the differences between the not-for-profit and for-profit environments.

\section{Establishing a Not-for-Profit Organization}

NPOs are a very popular way to conduct charitable operations because of their often tax-exempt status. However, they come with considerable responsibility in terms of establishment and ongoing compliance. The IRS has created a "Life Cycle of a Public Charity" document to assist organizers with this responsibility. The most popular form of tax-exempt NPOs is Internal Revenue Code section 501(c)(3) public charity organizations, which are organized for charitable purposes. The main reason why this form is so popular is that donors can receive tax deductions for contributions to these organizations. A substantial amount of documentation must first be prepared and filed with the appropriate agencies to gain this status. Then, once the organization is legally established and tax-exempt status is granted, annual filing and ongoing compliance requirements must be met (Wilson et al., 2007).

The first step in the process of establishing a tax-exempt NPO is to prepare articles of incorporation, complete with a separate document containing by-laws, and file them with the state in which the organizers wish to incorporate. This is no easy task and should be completed very carefully. Procuring the services of an attorney and an accountant is often necessary when preparing organizing documents and IRS applications. The articles of incorporation have an external focus that describes the purpose of the organization, while the by-laws have an internal focus that describes the functional policies and procedures of the organization. Once granted legal status separate from the incorporators, the organization now possesses the ability to carry out its business purpose, but is under oversight responsibility of the state due to its power to give legal life to an NPO. Next, the NPO must apply to the IRS for exemption from federal income tax. NPOs are granted tax-exempt status based on the 
primary purpose of the organization. In order to be considered a public charity, the entity must benefit the public at large, rather than just a small group of individuals. Once granted tax-exempt status, the organization is now also under oversight responsibility of the federal government (Wilson et al., 2007).

As a method of maintaining oversight, several annual filings with the state and federal governments as well as other ongoing compliance documents are required. NPOs are mandated by many states to file annual reports, disclosing its activities for the year and confirming its continued existence. Although no tax is generally due, NPOs are required by the federal government to file an annual informational tax return, also disclosing its activities for the year and confirming its continued existence. The federal filing requirement is often more comprehensive than the state, in that it includes a significant amount of financial information as well. Ultimately, the amount of information required depends on the size of the organization (Wilson et al., 2007).

\section{Financial Accounting and Reporting}

The not-for-profit designation implies that NPOs exist with goals other than earning a profit. According to Wilson et al. (2007), "not-for-profit organizations are characterized by the absence of owners and dependence on contributions, dues, charges for services, and investment income for revenue, rather than taxes” (pp. 555-556). Accordingly, a key objective of financial reporting for NPOs is to provide information about an entity's performance, rather than its profits, during a period. The FASB's objectives of financial reporting for not-for-profit agencies are to provide information useful in (1) making resource allocation decisions, (2) assessing services and ability to provide services, (3) assessing management stewardship and performance, and (4) assessing economic resources, obligations, net resources, and changes in them (Wilson et al., 2007, pp. 558-559). The financial reports certainly provide information about revenues and expenses, but they also provide nonfinancial information that relate to the goals and objectives of the NPO. If the financial statements of an NPO include only monetary measures, there is no way they can provide the information that external users will need to assess the entity’s performance (Granof, 2005).

In contrast to for-profit businesses, NPOs often establish the level of services they will provide first, and then set rates and other fees, as well as fundraising goals, to generate the revenues required to pay for them. NPOs are governed mainly by their budgets, not by the marketplace. In essence, expenses drive revenues, rather than the other way around (Granof, 2005). Like the commercial for-profit model of financial reporting, NPOs are required to present financial statements showing the results of the entity as a whole. That is, the FASB is interested in how entities report their overall financial position and results of operations. NPOs are permitted to present individual data by fund if they wish, as long as the comprehensive statements are also presented. To be in conformity with GAAP, the FASB requires a statement of financial position, a statement of activities, and a statement of cash flows, complete with notes to the financial statements, all prepared on the accrual basis of accounting. Comparative statements are encouraged, but not required (Wilson et al., 2007). 
This section explored the establishment of an NPO, discussed the generally accepted accounting principles followed in preparing the financial statements, and summarized the differences between the not-for-profit and for-profit environments. Its organizers should not take the establishment, ongoing compliance, and financial reporting of an NPO lightly. Accordingly, professional assistance should be procured when completing the complicated documentation. In fact, if done incorrectly, the NPO could risk losing its tax-exempt status (or may never be granted it) and could face serious penalties charged by both the state of incorporation and the federal government. Next, this article explores the accounting and reporting requirements of the federal government, colleges and universities, and health care organizations.

The federal government, institutions of higher education, and health care organizations all have much in common with business entities. However, the differences between them have profound implications for financial reporting. This is primarily because they are all required to follow complex accounting and reporting requirements that fall under the jurisdictions of various governing bodies. In this section, the accounting and reporting requirements between the federal government, colleges and universities, and health care organizations are compared and contrasted. More specifically, this section discusses the funds used, measurements of performance, and required financial statements for each different entity.

\section{Federal Government}

Wilson, Kattelus, and Reck (2007) note, "the federal government of the United States of America is the largest reporting entity in the world and is growing” (p. 467). As a result, accountability in the federal government is an immense political issue. Accountability for public revenues raised to meet the cost of government services has always been a responsibility of elected and appointed officials (Wilson et al., 2007). The U.S. Constitution left it to Congress and the executive branch to determine the form and content of financial reports and to implement and administer the accounting information systems used by the government. Historically, accounting for the federal government has been decentralized among the various agencies and departments, with each agency and department having its own accounting information system and report preparation methods (Granof, 2005).

There are currently three agencies with oversight responsibility for financial management of the federal government. Those agencies are the Department of the Treasury, the Office of Management and Budget (OMB), and the Government Accountability Office (GAO). Since the federal accounting and reporting system remains inadequate for an organization of the federal government's size and complexity, these three agencies are presently working towards coordinating the accounting information systems and report preparation methods of the various agencies and departments (Granof, 2005). The Federal Financial Management Improvement Act was passed in 1996 to help ensure that federal agencies corrected their poor accounting information systems and report preparation methods. The act presently requires major agencies of the federal government to submit audited financial statements and performance and accountability reports annually to the OMB (Wilson et al., 2007). 
Established in 1990, the Federal Accounting Standards Advisory Board (FASAB) retains primary responsibility for promulgating accounting standards for the federal government. However, it was not until 1999 when the FASAB received this designation from the American Institute of Certified Public Accountants (AICPA) as the generally accepted accounting principles (GAAP) standards-setter for the federal government (Patton \& Mosso, 2009). The FASAB was established to generate an improved structure for setting accounting principles and standards for the federal government. According to Wilson et al. (2007), "the role of the FASAB is to deliberate upon and make recommendations to the Principals on accounting principles and standards for the Federal Government and its agencies” (p. 472). Since its establishment, the FASAB has developed a comprehensive accounting model as well as detailed standards that address specific types of transactions (Granof, 2005). While the Financial Accounting Standards Board (FASB) and the Governmental Accounting Standards Board (GASB) focus their standards on external reporting, the FASAB focuses its standards on both internal and external reporting (Wilson et al., 2007).

Although FASAB's standards do not focus on fund accounting, Congress routinely passes laws that require the use of funds for compliance purposes. A sample of the fund types that could be found in federal government accounting include the general fund, special funds, revolving funds, management funds, trust funds, and deposit funds. The FASAB standards do, however, focus on government-wide reporting and as of 1997, the Department of the Treasury has been issuing an annual financial report that follows FASAB standards and is audited by the GAO. In addition, individual government agencies are required to prepare a general-purpose federal financial report consisting of a management's discussion and analysis, basic financial statements and related notes, required supplementary stewardship information, and other required supplementary information. The basic financial statements typically consist of a balance sheet, statement of net cost, statement of changes in net position, statement of budgetary resources, statement of financing, and a statement of custodial activity (Wilson et al., 2007).

Federal agency accounting is primarily directed at providing information for sound financial management of agency programs. It is important that these programs are managed efficiently while providing evidence of compliance with legal requirements. Therefore, federal agency accounting includes information needed for the management of agency resources as well as compliance (Wilson et al., 2007). In response to the need for management performance in the federal government, the Government Performance and Results Act was passed in 1993 with the intent to further improve federal accounting and fiscal management. The act requires agencies and departments to establish specific goals and objectives and report annually on the extent to which they achieve them (Granof, 2005).

\section{Colleges and Universities}

Wilson et al. (2007) note, "institutions of higher learning have long been dichotomized into public colleges and universities, which are governmental in nature, and private colleges and universities, which are nongovernmental and not-for-profit organizations” (p. 627). In terms of revenues, public institutions receive most of their resources from state appropriations and 
research grants, while private institutions receive most of their resources from tuition and fees, private gifts, and research grants. The GASB currently has jurisdiction over public colleges and universities, while the FASB has jurisdiction over private colleges and universities as well as for-profit business entities in the higher education market (Wilson et al., 2007). Accordingly, the GASB requires governmental (i.e., public) colleges and universities to follow the GASB pronouncements pertaining to special-purpose governments, with one loophole, while the FASB requires not-for-profit (i.e., private) colleges and universities to follow the FASB pronouncements pertaining to not-for-profit organizations (Granof, 2005).

The GASB loophole allows public colleges and universities to report as special-purpose governments engaged only in business-type activities. Therefore, those entities are only required to prepare a statement of net assets, statement of revenues, expenses, and changes in net assets, and a statement of cash flows, as well as a management's discussion and analysis. These statements must be prepared on a full accrual basis, complete with capital assets and depreciation; however, detailed fund financial statements are not required (Granof, 2005). The FASB requires private colleges and universities to report on the changes in unrestricted, temporarily restricted, and permanently restricted net assets of the entity as a whole, much like other nongovernmental not-for-profit organizations. A statement of financial position, statement of activities, and statement of cash flows is required by the FASB. The major differences that exist between public and private institutions arise in the areas of classification of net assets, operating and cash flows statement format, investments, pensions, and compensated absences (Wilson et al., 2007).

In terms of performance measures, decision-makers, oversight bodies, funding sources, and other constituents in the institutions regularly monitor financial and quantitative information as well as non-financial and non-quantitative information looking for indicators of successes and failures. Both public and private institutions are encouraged to provide information regarding service efforts and accomplishments and documentation of how well the institutions are achieving student learning outcomes and accomplishing their missions. In addition, regional and specialized accrediting agencies are very interested in performance measures for assessing quality on a continuing basis (Wilson et al., 2007).

\section{Health Care Organizations}

Wilson et al. (2007) note, "the health care industry in the United States changed dramatically in the last century. Today, health care organizations are complex entities that cross the private, public, and not-for-profit sectors” (p. 667). According to Krenek (2006), "of the 5,759 registered hospitals in the United States, 2,967 of those are not-for-profits; only 835 are for-profit institutions, with the remaining classified as governmental or other" (p. 16). Roughly, one-half of hospital health care is provided by not-for-profit organizations, although most providers of health care are actually for-profit groups of medical professionals who are simply associated with governmental or not-for-profit health care organizations. The American Hospital Association, the Healthcare Financial Management Association, and the AICPA have all contributed to the development of GAAP for health care organizations. In 
addition, both the FASB and the GASB have had an impact on the accounting and reporting requirements for these organizations (Wilson et al., 2007).

The GASB currently has jurisdiction over governmental hospitals and health care providers, which requires these entities to follow the GASB pronouncements pertaining to special-purpose governments. They may either be component units of another government or stand-alone governmental entities. Private (i.e., investor owned) and other nongovernmental not-for-profit health care providers fall under the jurisdiction of the FASB, and therefore must follow the FASB pronouncements pertaining to proprietary and not-for-profit entities. All health care organizations must provide a balance sheet or statement of net assets, a statement of operations or statement or revenues, expenses, and changes in net assets, and a statement of cash flows, complete with notes to the financial statements. In addition, the FASB requires proprietary and not-for-profit entities to prepare a statement of changes in equity. All health care organizations are allowed to use fund accounting for internal reporting purposes, particularly when accounting for revenues and expenses associated with grants, but are not required to do so (Wilson et al., 2007).

Revenues are recorded at their gross amounts when services are rendered, and any contractual adjustments are recorded as contra-revenue accounts, which will result in net patient service revenue. Services and noncash assets that are donated to a not-for-profit or governmental health care entity are generally recorded at their fair market value when received. Since all health care providers use full accrual accounting, the accrual process for expenses is generally the same as it is for any business organization, with one exception. This exception requires governmental health care organizations that follow GASB standards to recognize bad debts as an adjustment to revenue instead of an expense. Nongovernmental health care organizations, however, are allowed to recognize bad debts as an expense. Governmental health care activities that are part of a larger primary government are reported in governmental and internal service funds, while business-type activities are reported in enterprise funds (Wilson et al., 2007).

In terms of performance measures, a variety of ratios and benchmarks are used to evaluate health care organizations. A sample of typical measurements includes patient volume ratios, patient and payout mix ratios, productivity and efficiency ratios, and debt covenant ratios. These ratios are computed and then compared to other health care organizations of similar size and mission. Performance measures are typically used for both financial and nonfinancial decision-making and performance improvements (Wilson et al., 2007).

\section{Conclusion}

First, this article explored the establishment of an NPO, discussed the generally accepted accounting principles (GAAP) followed in preparing financial statements, and summarized the differences between the not-for-profit and for-profit environments. Second, this article explored the accounting and reporting requirements of the federal government, colleges and universities, and health care organizations. Users of the financial reports of these entities must be very careful when assessing financial and nonfinancial performance, as each entity 
follows accounting and reporting standards with unique differences. Generalizing across entities is not recommended due to these differences.

\section{References}

Granof, M. H. (2005). Government and not-for-profit accounting: Concepts and practices (3rd ed.). Hoboken, NJ: John Wiley \& Sons.

Krenek, B. H. (2006). Not-for-profits: Business basics for survival. Frontiers of Health Services Management, 22(4), 15-21. Retrieved from http://search.proquest.com/docview/203896150?accountid=27424

Patton, J., \& Mosso, D. (2009). Is the federal accounting standards advisory board independent? Can the federal accounting standards board be more independent? The Journal of Government Financial Management, 58(3), 60-63. Retrieved from http://search.ebscohost.com/login.aspx?direct=true \&db=bth\&AN=44810201\&site=eds-live

Tolbert, S. H., Moore, G. D., \& Wood, C. P. (2010). Not-for-profit organizations and for-profit businesses: Perceptions and reality. Journal of Business \& Economics Research, 8(5), 141-153. Retrieved from http://www.cluteinstitute.com/ojs/index.php/JBER/article/view/726

Wilson, E. R., Kattelus, S. C., \& Reck, J. L. (2007). Accounting for governmental \& nonprofit entities (14th ed.). New York, NY: McGraw-Hill/Irwin.

\section{Copyright Disclaimer}

Copyright for this article is retained by the author(s), with first publication rights granted to the journal.

This is an open-access article distributed under the terms and conditions of the Creative Commons Attribution license (http://creativecommons.org/licenses/by/3.0/). 